\title{
ITALIAN SOCIETY UNDER ANGLO-AMERICAN BOMBS: PROPAGANDA, EXPERIENGE, AND LEGEND, 1940-1945
}

\author{
CLAUDIA BALDOLI \\ Newcastle University \\ A N D \\ MARGO FINCARDI \\ University of Venice
}

\begin{abstract}
A B STRACT. The Italian experience of being bombed has been neglected in the historiography of the Second World War, especially in English. This marginalization is not justified by the record of events; according to official estimates, Italian civilian victims of bombing numbered around 6o,ooo. The reaction of the Italian population to air raids was carefully evaluated and discussed by the Allies, who decided to hit civilians living near industrial areas with a view to testing their psychological resistance. The article focuses on the civilians' reactions to death coming from the sky, by examining their response to both Anglo-American and Fascist propaganda, and to the experience of the raids at different stages of the war. It analyses the ways in which civilians coped with the collapse of state defences (including the creation of legends and the spreading of rumours independent of state propaganda), and the psychologically complex and shifting response to bombers who introduced themselves as liberators. The research presented is based on archival sources, particularly prefects' reports from different parts of Italy to the Ministry of Interior, on both Anglo-American and Fascist propaganda, newespaper articles, and civilians' diaries.
\end{abstract}

In recent years a renewed interest in bombing campaigns during the Second World War has prompted the appearance of narratives of the German experience and wider explorations of the ethics of bombing. ${ }^{1}$ These accounts form a darker parallel to those accounts of the London Blitz, both conventional and critical,

School of Historical Studies, Armstrong Building, Newcastle University, Newcastle upon Tyne, NEI $7 R U$ claudia.baldoli@ncl.ac.uk

Dipartimento di Studi Storici, Malcanton Marcorà, Università di Venezia, Dorsoduro3484/D, 30123 Venezia fincardi@unive.it

1 For example Hermann Knell's To destroy a city: strategic bombing and its human consequences in world war II (Cambridge, MA, 2003); A. C. Grayling's Among the dead cities (London, 2006). 
familiar to British readers. ${ }^{2}$ Although in Italian there are a few recent accounts of the bombing of Italy (some rather journalistic), including several local histories, the Italian experience of bombing has been neglected in the historiography of the Second World War, especially in English. The events recorded do not justify this marginalization; according to official estimates, there were around 6o,ooo Italian civilian victims of bombing, a death toll very similar to that of British civilians under German attack. ${ }^{3}$

The bombing of Italian cities began a little more than twenty-four hours after Mussolini's declaration of war on France and Britain. The last bombs fell on Italy at the beginning of May I945 along the route to the Brenner pass to obstruct German troops returning home. During the five years in between, almost every Italian city experienced bombing, first by the British, then by the Americans and, following the Allied invasion in July I943, also by the Germans. Italy therefore experienced attacks by enemies as well as by 'friends', whose bombing also brought with it the promise of liberation.

On II June I940 Turin was bombed for the first time, followed among others by Genoa, Milan, Naples, and Taranto. The historic centre of Venice was spared, but the surrounding region was not, as it included a sprawling industrial concentration, of oil refineries in particular, at Mestre. Genoa and surrounding towns were one long industrial strip-city, containing refineries, shipyards, steel mills, and the Ansaldo works. Milan was Italy's economic and industrial hub, and in Turin FIAT Mirafiori and related plants were paramount military objectives.

The bombing campaigns that followed in I942, and particularly in I943, were much more intense than those of I940-I. By the first half of 1943 all the Italian regions had been attacked. In the spring of 1943 , following heavy raids in Turin, Milan, and Genoa, the last of which had been turned into little more than a heap of rubble, workers went on strike and demonstrated for peace. Rome was bombed for the first time on I9 July I943; six days later, the Fascist regime fell, and the king appointed Marshal Pietro Badoglio as prime minister. Following the Allied landings, southern Italy was bombed by both the Allies and the Germans: in August the Germans bombed Palermo while at the same time the Allies were bombing Taranto and Naples. The Italian armistice, declared on 8 September I943, divided Italy between an Allied southern area and a northern area dominated by the Germans, if nominally under Mussolini's Social Republic. The

${ }^{2}$ See Gavin Mortimer, The longest night (London, 2005); Angus Calder, Myth of the blitz (London, I99I).

${ }^{3}$ Giorgio Bonacina, Obiettivo: Italia. I bombardamenti aerei delle città italiane dal I94o al I945 (Milan, I970); Marco Gioannini and Giulio Massobrio, Bombardate l'Italia: storia della guerra di distruzione aerea, 1940-1945 (Milan, 2007); Marco Patricelli, L'Italia sotto le bombe (Rome and Bari, 2007). The best account is by Gabriella Gribaudi, Guerra totale: tra bombe alleate e violenze naziste. Napoli e il fronte meridionale, I940-I944 (Turin, 2005); a recent book by Umberto Gentiloni Silveri and Maddalena Carli, Bombardare Roma: gli alleati e la città aperta, 1940-1944 (Bologna, 2007), analyses the Allied discussion about the bombing of Rome. 
armistice meant that the Allies were no longer targeting an enemy country, although Italian civilians continued to be the object of attack alongside German military targets in Italy ${ }^{4}$ to the extent that two-thirds of the total number of Italian casualties occurred between the armistice and the end of the war. ${ }^{\mathbf{5}}$

Between I940 and 1945 Italian cities experienced intermittent phases of intense attack, particularly in the north and in the south. Central Italy was not attacked until the spring of 1943 , but became the most bombed part of the country over the subsequent fifteen months. ${ }^{6}$ The Americans were mostly responsible for the bombing of southern Italy and the British the north: while the RAF bombed communication and industrial targets at night, the American Army Air Force attacked during the day using so-called precision bombing. However, the high number, large scale and high altitude of American operations produced results that were as devastating for the population as those of British 'area bombing' in northern Italy.

According to Stephen Harvey, who has written the only existing article in English on the subject, the experience of being bombed - rather than military defeats or Mussolini's failure as a war leader - was perhaps the largest single contributory factor in Italy's war weariness and in the collapse of Italian morale. ${ }^{7}$ This may be an exaggerated claim, since military defeats and lack of food also contributed to the collapse of popular morale, but air raids were certainly the most visible sign of the war and the one that caused most panic.

The first air attacks did not cause large-scale damage or claim many victims, but the evident ease with which the enemy passed over defences that Mussolini had claimed were impenetrable provoked fear and anxiety. While British attacks on France were aimed, in principle, at specific targets linked to the German occupiers and not at French civilians, ${ }^{8}$ in northern Italian cities the British decided from the start to hit the civilian population living near industrial areas, with a view to testing its psychological resistance. The conviction that Italy was the 'soft underbelly' of the Axis was evident from the Allied view of the Italian

\footnotetext{
${ }^{4}$ After September 1943, industrial and communications objectives in northern Italy and immediate tactical objectives on or near the front were paramount. See Lutz Klinkhammer, L'occupazione tedesca in Italia, 1943-I945 (Turin, 2007; Ist edn I993).

5 During the course of the war RAF Bomber Command and the VII and XV US Army Air Forces dropped a total of 2,697,473 tons of bombs in the European theatre, I,235,609 by Bomber Command and I,46I,864 by the American bomber forces. Of this total quantity some $5^{\circ} 3$ per cent (I,356,829 tons) were dropped on Germany and I3.7 per cent (369,554 tons) were dropped on Italy. See United States Strategic Bombing Survey, Over-all report (European war), Washington, DC, 3o Sept. I945; Richard Overy, Bomber Command, 1939-1945 (London, 1997), p. 209; Arthur Tedder, Air power in war, Air Ministry Pamphlet 235, Sept. I947, Diagram 5.

6 Gioannini and Massobrio, Bombardate l'Italia, p. II.

7 Stephen Harvey, 'The Italian war effort and the strategic bombing of Italy', History, 70 (I985), pp. 44-5. For a summary of Italian secondary sources on the subject, see also Philip Morgan, The fall of Mussolini (Oxford, 2007); and Tobias Abse, 'Italy', in Jeremy Noakes, ed., The civilian in war: the home front in Europe, Japan and the USA in World War II (Exeter, I992), pp. I04-25.

8 Lindsey Dodd and Andrew Knapp, "How many Frenchmen did you kill?" British bombing policy towards France (I940-I945)', French History, 22 (2008), pp. 469-92.
} 
armed forces to their assessment of the Italian home front which, from as early as I940, the British believed would collapse under bombing more easily than its German counterpart. The Italian 'psychology' was considered 'not suited for war', ${ }^{9}$ and the British therefore expected that bombs would have political as well as military consequences. The hope was that bombing would persuade Italians to withdraw their support for the regime, which in turn might lead to Italy's elimination from the war.

The British government discussed Italian morale throughout the war. After the raids of 1942 on Genoa and Milan, Foreign Secretary Anthony Eden warned that anti-British sentiment had increased among the Italian population. The British feared that the Italian reaction to the raids could develop as it had in Britain in I94I, when German bombing served to strengthen rather than undermine national cohesion against the enemy. Nonetheless, the British conviction was that panic together with a clever use of propaganda could persuade Italians that the Fascist government, and not the British, were to blame. ${ }^{\mathbf{1 0}}$ After the fall of the regime in I943, during a meeting at the Dominions Office, Eden suggested that bombing northern Italian towns at that point "would weaken the hold of the Italian government and make the prospect of Italy dropping out of the war more favourable', although Churchill seemed less certain, wondering if 'the effect of bombing might interrupt a favourable trend in the feelings of the Italian people'. ${ }^{11}$ Nevertheless, the decision taken was in favour of bombing. Two days later Bomber Command had been 'instructed to engage targets in Northern Italy', an action calculated 'to increase the pressure by the Italian people on their government for peace moves'. ${ }^{2}$

Bombs were often anticipated or followed by leaflets: Allied propaganda material was dropped on Italian cities and on Italian soldiers in the Mediterranean. The propaganda aimed to persuade the Italians to protest against Fascism, and particularly encouraged soldiers and civilians to refuse to collaborate with, and to be hostile to, the Germans. The population therefore became a 'hostage' of the war, ${ }^{13}$ subject to attacks and at the same time encouraged to revolt against Fascism. In particular, this was the case with Italian women who, in the absence of much of the male population, were disproportionately affected by mass violence and sustained trauma. Women were at the centre of a dislocated family life, while it was women who looked after refugees and searched for food. Writer Miriam Mafai has underlined the aspect of resignation rather than protest during the period of bombing and hunger that typified a new way of living dominated by fear. ${ }^{14}$ However, documents in Italian archives demonstrate that resignation was

${ }^{9}$ Gribaudi, Guerra totale, p. 48 .

${ }^{10}$ Memorandum of the foreign secretary, Anthony Eden, 20 Nov. 1942, The National Archives (TNA), Kew, Foreign Office (FO) 371/33228, cited in Gribaudi, Guerra totale, p. 79.

11 'Extract from D.O. (43) 6th meeting', 28 July I943, TNA, Kew, AIR 20-2565.

12 'Most secret - secretary of state', 3 I July 1943, TNA, Kew, AIR 20-2565.

${ }^{13}$ Gribaudi, Guerra totale, p. 8o.

${ }^{14}$ Miriam Mafai, Pane nero: donne e vita quotidiana nella seconda guerra mondiale (Milan, I987), p. I23. 
not the only response $;^{15}$ women played an active part in the protests against the regime's inefficiency in its protection of civilians. Women also contributed to the sustenance of a separate world of myth and rumour which challenged the prevailing social propaganda generated by the state, and they were also the main target of the Allied leaflet campaigns.

This article will focus on civilian reactions to death from the sky by examining responses among the population to Anglo-American and Fascist propaganda and to the experience of air raids at different stages of the war; it will analyse the ways in which civilians coped with the collapse of state defences (including the creation of legends and the spreading of rumours independent of state propaganda), and the psychologically complex response to bombers who introduced themselves as liberators. The research presented here is based on archival sources, particularly the reports of prefects from different parts of Italy to the interior ministry, Allied and Fascist propaganda, newspaper articles, and civilian diaries. ${ }^{\mathbf{1 6}}$

Until the summer of I943, with the exception of Sicily, Calabria, and the port of Naples, air raids on Italy took place mostly at night. In the mornings, as the curfew ended, people found the ground littered with messages dropped overnight. Contact with the enemy increased from the autumn of 1942 through this form of one-way communication. For those interested in maintaining some relationship with the Allies, the only option was to act in accordance with the advice in the leaflets - to protest against the war and against the authorities. News of impending defeat did not arrive only on the airwaves from Radio London, Radio Moscow, Radio Algiers, or, from 6 August i943, Radio Palermo (controlled by the Allied Psychological Warfare Branch), but also from these propaganda leaflets. ${ }^{17}$ One of the expressions of war propaganda most familiar to civilians in every country was the exhortation on posters: 'Quiet! The enemy is listening!', accompanied by the image of ugly spies. Instead, these small leaflets delivered the words of far-away Intelligence experts dispensing reassurance in the shape of instructions which evaluated and discussed the population's war experience, even providing political and practical advice on how to come out of it - and did so in Italian.

15 In particular the papers of Ministero dell'Interno, $A_{5} G$, Seconda Guerra Mondiale, in the Archivio Centrale dello Stato, Rome.

16 The work presented here is part of a collective research project sponsored by the Arts and Humanities Research Council on 'Bombing, states and peoples in western Europe, I940-1945', www.centres.ex.ac.uk/wss/bombing. Thanks to Andrew Knapp, MacGregor Knox, and Richard Overy for their comments on the article and to the rest of the team for many stimulating discussions.

17 On radio listening during the war, see Maura Piccialuti Caprioli, Radio Londra, I939-1945 (Rome and Bari, I979); Gianni Isola, Abbassa la tua radio per favore ... Storia dell'ascolto radiofonico nell'Italia fascista (Scandicci, I990); Lamberto Mercuri, Guerra psicologica: la propaganda anglo-americana in Italia, $1944^{2-1946}$ (Rome, I983). 
The collective voice of the Italians had been manipulated and caged for almost twenty years by the Mussolini dictatorship's powerful media apparatus; with successive military defeats for the Fascists, a hesitant but vast public opinion was being reborn, which was extremely sensitive to the instruments of communication utilized by the British and the Americans in their psychological war. ${ }^{18}$ For many, those messages hastened the shocking realization of facts already perceived: the coming defeat; the harmful consequences from keeping Mussolini and the Partito Nazionale Fascista (National Fascist Party) (PNF) in power; and the presence of a tyrannical German ally. As PNF and ministry of interior reports on public morale demonstrate, the disastrous Greek campaign with the loss of Albania in November 1940, the concomitant Fleet Air Arm attack at the naval base of Taranto, and the successful British counter-offensive in North Africa in January I94I destroyed the regime's prestige for good. Likewise, the stalling of Rommel in Egypt and of the Germans at Stalingrad by autumn I 942 persuaded large numbers of Italians that the Axis was doomed. The US-British landings in French North Africa combined with intensified air bombardment on Italy powerfully reinforced that source of popular detachment from the regime. ${ }^{19}$ Allied leaflets solicited a definitive, but also painful, dissociation from the myth of Mussolini, and persuaded the population that bombing had to be accepted as a means to accelerate the end of the dictatorship and of the war.

Discovering such signs of the enemy's presence, together with the surprise of reading practical friendly advice in Italian, could provoke sufficient emotion to ensure that the messages were repeated, or that a copy of the leaflet was passed on to others. It was commonly reiterated that the Anglo-American 'enemy/friend' bombed and killed Italians because of their support for the German war effort, for which Fascism was responsible. At times, such repetition produced false news or exaggeration, as in the case of the bombing of Turin on I9 November I942, when the population claimed it had received warning leaflets from British pilots prior to the attack, as if this somehow constituted the provision of a charitable public service - an apology for Allied actions yet more extraordinary considering the evident inadequacy of anti-aircraft weaponry and shelters to protect people. ${ }^{20}$

The content of leaflets changed over time, particularly when America entered the war. While the British tended to communicate with Italians through an emphasis on anti-German propaganda and attempts to create panic, the Americans injected a more friendly message, namely the recognition that Italians could still redeem themselves by collaborating with the Allies.

18 See Simona Colarizi, L'opinione degli italiani sotto il regime, 1929-1943 (Rome and Bari, I991). On these phenomena see also Albert O. Hirschman, Exit, voice and loyalty: responses to decline in firms, organizations and states (Cambridge, MA, I970).

19 For a brief but co-ordinated analysis, resting on primary material on both elite and popular opinion, see MacGregor Knox, 'Das faschistische Italien und die "Endlösung", I942/I943', Vierteljahrshefte für Zeitgeschichte, 54 (2007), pp. 83-6.

20 Emanuele Artom, Diari di un partigiano ebreo: gennaio 1940-febbraio 1944, ed. Guri Schwarz (Turin, 2008), p. $3^{2 .}$ 
British anti-German leaflets began circulating in Italy as early as August I940. A typical title was British methods - German methods. ${ }^{21}$ The image of the Germans as barbarians was constantly used to demonstrate to Italians that Mussolini's alliance with Hitler was a mistake for which the population now had to pay. The anti-German element took the form of appeals to Italy's past struggles for independence (although Austria, the real enemy of Italian unification, no longer existed): 'Italians! Your glorious predecessors led by the House of Savoy and helped by France and Britain kicked the Germans off Italian soil. Mussolini has called them back. ${ }^{\mathbf{2 2}}$ Leaflets targeted soldiers as well as civilians. The same argument was used in communication with Italian soldiers in Addis Ababa in I94I. One example began: 'Italians! Mussolini has called back the barbarians from the north', followed by a brief summary ranging from the Visigoths in the fifth century to Austria in the eighteenth, via the Lombards, Frederick Barbarossa, and Charles V. Italians were reminded that the British had been on their side during both the Risorgimento and the First World War; the names of Mazzini, Garibaldi, and Cavour were used to reinforce national pride in the 'right direction'. ${ }^{23}$

Leaflets dropped on Italian cities at the beginning of I94I entitled The truth informed the population that Mussolini had abandoned the Italian empire in Africa to its destiny, that the Italian army was losing in Greece, and that there had allegedly been public demonstrations against German soldiers in Rome and Milan. These types of leaflet were followed by others which focused on the threat to civilians posed by the bombs. A typical conclusion was: 'Italian people! ... We did not want to fight against you. ${ }^{24}$

In January I94I, a leaflet entitled Italians in Ethiopia! informed soldiers stationed there of RAF operations in Libya, with the intention of terrorizing them into ceasing to fight:

Bardia was incessantly bombed for $3^{0}$ hours. During that time, the Italian aircraft in Libya did not even dare to intervene. We let you draw your own inevitable conclusions ... do you really believe that in such conditions you can resist against a world empire and against the long repressed hostility of the Ethiopian people ?25

Emphasis was also given to the ideological aspects of the British war: British soldiers were guided by the love of freedom and the right of the oppressed peoples, their flag carried with it freedom of speech and the press. ${ }^{\mathbf{2 6}}$

21 'Opuscoli inglesi di propaganda antigermanica', prefect of Como to Ministry of Interior, 29 Aug. I940, Archivio Centrale dello Stato (ACS), Ministero dell'Interno (MI), Direzione Generale Pubblica Sicurezza (DGPS), IIGuerra Mondiale (IIGM), A5G, b. 20.

${ }^{22}$ i Feb. I94I, ACS, MI, DGPS, IIGM, A5G, b. 20.

23 'Volantini lanciati su Addis Abeba da aerei nemici durante l'incursione del giorno II/2/I94I':

'La verità', 6 Feb. I94I, ACS, MI, DGPS, IIGM, A5G, b. 20.

24 'La verità', i Feb. I94I, ACS, MI, DGPS, IIGM, A5G, b. 20.

25 'Volantino lanciato su Chismaio il I5 gennaio I94I', in ACS, MI, DGPS, IIGM, A5G, b. 20.

26 Ibid. 
The other aim of Allied propaganda was to create panic among civilians. Across Italy, from Verona to cities in Apulia, between August and December I942, a leaflet was dropped that read: 'The real war is approaching - why we bomb you.' A map of Italy indicated bombed cities and listed those about to be bombed: Milan, Genoa, Turin, Taranto, Naples, Catania, Palermo, Cagliari. ${ }^{27}$

Women were the most important target of the leaflets dropped on cities. Indeed, their content suggests that the British believed women's anti-war action could contribute to the collapse of morale. That this was a crucial element was evident also from Fascist counter-propaganda leaflets, which were distributed by the Fasci to women in order to contradict the British arguments. A British leaflet of I94I made an appeal to the eternal condition of women in war - the unbearable pain of the death of sons, husbands, and brothers in war:

What do the trumpeted victories of Hitler in Russia mean for you if your son is nothing more than a shapeless mass of flesh crushed by Russian tanks? ... Is it in order to please Hitler and Mussolini? ... You can put an end to these horrors! Go to the Fascio; scream and shout that you want the end of this war. Write on the walls that you want peace. Britain wants peace with Italy, but Mussolini is blocking the way. ${ }^{28}$

In this way, a major attempt was also made to break the propaganda of twenty years that proclaimed women's revolutionary role in the Fascist regime and the link of faith and devotion that was supposed to exist between Italian women and Mussolini. The Fascist answer to the British insisted in trying to keeping that role alive: 'Italian woman, perfidious Albion ... cannot defeat your sons and wants you to stab them in the back ... asking you to have fear for them while they have none; ... if Italian women resist, the war is lost for England. ${ }^{29}$ Fascist leaflets also underlined the fact that British and American methods included the bombing of civilians, hospitals, churches, and houses and not just military targets, and insisted that Italians cultivate hatred for the enemy. ${ }^{\mathbf{3 0}}$ However, the effectiveness of Fascist propaganda was limited by the regime's inability to sustain the myth of victory or to defend civilians under attack from bombs. In addition, the regime could count at this point only on a virtually non-existent distribution network for its propaganda: it could not drop leaflets from the sky, and propaganda was limited to distribution at PNF headquarters or public celebrations, which became increasingly fewer and smaller as the war progressed. Allied success in the propaganda war was also due to the care with which 'Italians' were distinguished from 'Fascists' in their literature; the Allies claimed that they were forced to bomb civilians because of Mussolini, but they did not regard the population as an enemy. For example, following the raid of 20-I July I94I, the citizens of Naples read, on leaflets dropped all over the city:

\footnotetext{
${ }^{27}$ Legione territoriale Carabinieri di Soave, 30 Dec. 1942, and prefect of Bari to Ministry of Interior, 6 Aug. I942, ACS, MI, DGPS, IIGM, A5G, b. 2 I.

28 British leaflet dropped on Italian cities in I94I, in ACS, MI, DGPS, IIGM, A5G, b. 20.

${ }^{29}$ In ACS, MI, DGPS, IIGM, A5G, b. 23, n.d., probably I942. 30 Ibid.
} 
Neapolitans! We British, who had not been at war against you so far, are sending you this message. Last night we bombed Naples. We did not want to bomb you, Neapolitan citizens ... But we have been forced to bomb your city because you allow the Germans to make use of your port.

Similar leaflets were found in Sicily and in Genoa in the same month. ${ }^{31}$

After the fall of the Fascist regime on 25 July 1943, Marshal Badoglio, now prime minister, declared that the war against the Allies would continue. As a result, Anglo-American bombing continued. Bombing during Badoglio's fortyfive-day rule was designed, together with anti-German propaganda, to intensify the pressure on the prime minister to sue for peace by suggesting that worse attacks could follow. ${ }^{32}$ The bombing of German cities was used as a threatening example. The issue of The Soldier's News, distributed by the RAF and by the USAAF, dated I6 August I943, opened with headlines 'Hamburg has become the city of death' and 'Will it be the same in Italy? '33 After 8 September, when Italy finally capitulated, bombing continued on German-occupied Italy while the population was encouraged to perform acts of sabotage against the occupiers.

\section{I}

Prefects' reports of a population enthusiastic about the war were few even in I940. However, a feeling that the war was just and inevitable was widespread between May and July i940. In the south, despite popular complaints about poverty and strong criticism of the local authorities, a police officer could write: 'faith in the Duce is however full and unconditional and it is generally believed that $\mathrm{He}$, as always, will be able, with firm hand, to lead Italy to the complete realization of its destinies'. ${ }^{34}$ Both soldiers and their families demonstrated 'tranquil mind and full faith in the destinies of the fatherland, and in the happy conclusion of the war'; 'the sense of duty towards the country is widespread'. ${ }^{35}$ The behaviour of local Catholic churches (always under observation since the church remained the only autonomous area of civil life in Italy) was recorded everywhere as laudable and patriotic. ${ }^{36}$ The church was indeed patriotic in the sense that it did not resist mobilization and did not criticize the regime, particularly during the first stages of the war.

31 Dropped on Naples and the surrounding province in July r94I ; Commissario di PS to Ministry of Interior, Genoa, 4 Oct. I94I, ACS, MI, DGPS, IIGM, A5G, b. 20. 'Manifestini di propaganda antifascista': 'Bilancio del primo anno di guerra fascista'. Prefect of Palermo to Ministry of Interior, 5 Oct. I94I, ibid.

32 'C.A.S. to Air Chief Marshal Tedder', 30 July i943, TNA, Kew, AIR 8-777.

${ }^{33}$ In ACS, MI, DGPS, IIGM, A5G, b. 2I.

34 'Provincia di Potenza', police general inspector to the head of police, 27 May i940, ACS, MI, DGPS, IIGM, A5G, b. 25 .

${ }^{35}$ Prefect of Caltanissetta to Ministry of Interior, Io Aug. I940, and police general inspector of Bari to the head of police, I5 July I940, ACS, MI, DGPS, IIGM, A5G, b. 25.

36 Ibid. 
Even during this period, however, a Naples police inspector could report that 'there are still those who, cowards by nature (first of all lower-class women), look resigned'. The main reason for this was that the first air-raids, and their first civilian victims, had had a powerful impact on the population. The bombings of Turin and Palermo, he continued, 'laid bare a deficient anti-aircraft defence'. ${ }^{37}$ The population of Taranto worried about the scarcity of shelters and began to spread negative rumours concerning the behaviour of local authorities. The prefect was said to be safe in his palace in the countryside, with the same said about other authorities who found 'more tranquil residence' outside the city. Most of the population could not be evacuated: in Taranto it was observed that thousands of people were 'crammed into the old town in an incredible way. One thus thinks with terror about a possible air raid. ${ }^{38}$

News began to circulate in November r940 about events in Greece and the bombing of Taranto. ${ }^{39}$ Soldiers moving from Taranto's military base to other port cities spread this, making an unfavourable impression on the local populations - although prefects could still add 'without casting doubts on the final victory'. ${ }^{40}$ Italians received official as well as unofficial information, though the ways in which information was censored and filtered by the regime (for example, war bulletins mentioned 'air incursions' without explaining the consequences) meant that Italians had to provide their own interpretations.

Another aspect of the raids mentioned in prefects' reports throughout the entire period of the war was the blackout. From the very first bombing operations in Italy, RAF planes crossing the Alps were welcomed by the sight of Milan and Genoa fully illuminated. ${ }^{41}$ Non-compliance with the blackout is evident not only from the prefects' letters, but also from many newspaper articles and from the reports in the files of the interior ministry and the air ministry citing problems of public order. In September i94I, Il Popolo d'Italia complained about the indiscipline of most citizens in Milan in ignoring the blackout. ${ }^{42}$ Similar news came from other newspapers; for example, Il Resto del Carlino denounced the fact that in Bologna houses were brightly lit and cars and bicycles drove with full lights. The reason for such disregard, the journalist thought, was a misplaced optimism. ${ }^{43}$

Remarkably complicated measures for anti-aircraft protection were established as soon as Italy entered the war in June i940. Instead of having one system for the whole country, there were three levels: P ('prominent'), M ('medium'),

\footnotetext{
37 Area inspector of Naples to Ministry of Interior and the head of police, 29 June I940, ACS, MI, DGPS, IIGM, A5G, b. 25 .

38 'Relazione sullo spirito pubblico in Puglia', area general inspector to Ministry of Interior and to the head of police, 29 June i940, ACS, MI, DGPS, IIGM, A5G, b. 25.

39 Questore (police chief) of Ancona to Ministry of Interior, I9 June and i6 Nov. I940, ACS, MI, DGPS, IIGM, A5 G, b. 25 .

40 'Operazioni belliche e spirito pubblico', prefect of La Spezia to Ministry of Interior, I5 Nov. I940, ACS, MI, DGPS, IIGM, A5G, b. 25. $\quad 41$ Overy, Bomber Command, I939-I945, p. 86.

42 'Milano. Troppi contravventori alle norme sull'oscuramento', Il Popolo d'Italia, 4 Nov. I94I.

43 'Contro un malinteso ottimismo - una più stretta osservanza alle norme sull'oscuramento', Il Resto del Carlino, 23 Apr. I94I.
} 
$\mathrm{S}$ ('scarce'). This meant that in some areas the building of shelters was less urgent, or the blackout could be applied less widely. Cities were divided into those three categories, ${ }^{44}$ blackout hours were decided, and were changed almost every month as the time of sunset changed. ${ }^{45}$ The complicated system of rules ultimately left a lot of room for local and even personal interpretations. In Rome, in November I940, the questore wrote to the prefect: 'Among the citizens there is a growing tendency towards conflicting interpretations of the time in the morning at which the blackout is supposed to end. While some stick in a rather subjective way to the concept of dawn, others follow the most varied times.' Police intervention on the question caused discussions, rows, and protests. ${ }^{46}$

Non-compliance with blackout regulations should not be construed, particularly in the first years of the war, as resisting the war effort, let alone an expression of pacifism or anti-Fascism, but of the difficulties of adapting society to the dynamics of war. Complicated rules suddenly had to be observed by a population that was not used to them. Moreover, because the system for sighting approaching enemy aircraft was imprecise, many of the frequent alarms were false. ${ }^{47}$

In the organization of shelters, property owners were required to co-operate with the Fasci and the authorities. This seldom happened and never without difficulties. The owners of apartment blocks generally refused to spend money on shelters, which led to protests from tenants who organized committees, gathered support and sent petitions to local authorities. For example, after one year of war, Naples still had no proper shelters. ${ }^{48}$ Prefects wrote to the police chiefs or to the Ministry of the Interior, to ask for help. ${ }^{49}$

In I94I-2, the fear of bombing turned to panic when the alarms sounded and people could not find shelters. The prefect of Milan commented that this knowledge had persuaded the population that if Milan were bombed, it would be a slaughter. The anti-aircraft protection system could not force property owners to spend money on shelters, and many owners had 'influential friendships' which protected them. This situation remained unchanged at the end of 1942 , when the existing shelters were not reinforced despite regulations since i940. While the

44 Ministry of War, Ufficio Protezione Anti Aerea, to the prefects and regional military authorities, Io June I940, ACS, Ministero dell'Aeronautica (MA), Gabinetto (Gab), Affari Generali (AG), I940, b. 82 .

${ }^{45}$ Ministry of War, Ufficio Protezione Anti Aerea, to the prefects, I3 Nov. I940, ACS, MA, Gab, AG, I940, b. 82.

46 'Oscuramento', from questore to prefect of Rome, 27 Nov. I940, ACS, MI, DGPS, IIGM, A5G, b. 62 .

${ }^{47}$ Italian radar research, mostly by the navy, was by the late ig3os quite advanced by international standards, but procurement and production lagged.

48 Prefect of Naples to Ministry of Interior, 4 Jan. I94I, and police informer to head of police, 25 Apr. I94I, ACS, MI, DGPS, IIGM, A5G, b. 62.

${ }^{49}$ Help never came from the head of police, Carmine Senise, who later recalled in a memoir of those years that all Italians were already against the war and hostile to the regime in I94o, and he simply tried to avoid excessive damage to the nation (Carmine Senise, Quando ero capo della polizia, I940-I943 (Rome, I946). 
Milanese rich could move to their houses on the lakes, the authorities did not know what to do about the working classes, whose presence - most notably in the shape of women's protests over food shortages - began to be regularly felt in most of the town halls in the province $:^{\mathbf{5 0}}$ 'if the attacks become as intense as they were in Genoa, how will we be able to evacuate? ${ }^{\mathbf{5 1}}$

The bombing of Genoa showed how close the home front was to collapse. Following heavy bomb attacks, areas with no shelters saw popular revolts. In October I94I protesters, mainly women, forced their way into rich owners' shelters by throwing stones. In November, entire areas of the city were in revolt. When the police tried to intervene, they were attacked by the crowd. ${ }^{\mathbf{5}}$ At the end of 1942 , as the situation continued to worsen, such protests became ever more widespread. Hundreds of families were living in tunnels in the city centre. When one flooded, overcrowded after an alarm, scenes of panic soon turned to angry shouting against the war, the Fascist authorities, and the government. Women marched to the prefettura and to the Fascio: 'the usual phrases against war, against the government and against the authorities were heard' ${ }^{53}$ This was precisely what Anglo-American leaflets were pleading for and, from the autumn of I942, a relationship began generally to emerge between external (Allied) solicitation and social protest.

The Fasci's publications were filled with pictures of destroyed homes, hospitals, and churches and portrayed Fascists helping women and children. A pamphlet from Genoa carried a sentence by the local party head: 'from the rubble the will to resist, in the eternal hatred of a people, has risen greater and stronger than ever ... In the large Fascist family everyone has found their home, their affections. ${ }^{54}$ This wishful propaganda had become powerless to influence public opinion between the winter of 1942 and the spring of I943. Scenes like those from Genoa in 1942 were repeated, more violently, in Turin. In June and July I943, hundreds of people broke into and entered hotels and shelters armed with picks. These were not always cases of anti-Fascism. There were also cases of tenants' committees who claimed still to believe in victory but demanded justice against rich landlords, the real anti-patriots: 'is there no confino for some people? This is the worst defeatism. ${ }^{55}$ Similar events occurred in Rome. Despite the fact that the airport at Ciampino was in danger of being bombed, there were still no shelters in

\footnotetext{
50 For women's protests in 1942, see the reports of local authorities of the Milan province in Archivio di Stato di Milano, Gabinetto della Prefettura, $\mathrm{C}_{2} 67$.

51 Prefect of Milan to Ministry of Interior, I2 July I94I, 2I Oct. I942, 2I Nov. I942, ACS, MI, DGPS, IIGM, A5G, b. 62 .

${ }^{52}$ Prefect of Genoa to Ministry of Interior, 20 Sept. I94I, 20 and 26 Oct. I94I, ACS, MI, DGPS, IIGM, A5G, b. 62.

${ }^{53}$ Prefect of Genoa to head of police, I5 Dec. I942, ACS, MI, DGPS, IIGM, A5G, b. 62.

54 PNF - Federazione dei Fasci di Combattimento di Genova, Genova 1942 (I942).

55 'Un gruppo di famiglie abitanti nella zona di Porta Susa', 26 June i943, and prefect of Turin to Ministry of Interior, I7 July I943, ACS, MI, DGPS, IIGM, A5G, b. 62.
} 
the town in 1943 and the local population protested in the Piazza Venezia 'to invoke from the Duce the most vigorous intervention' ${ }^{\mathbf{5 6}}$

Contradictory expectations, exasperation at the continued alarms and raids, and exposure to Allied propaganda all produced confused feelings. The Turin crowd running toward the shelters in November 1942 demonstrated inconsistent emotions, fearful but at the same time hopeful that the attack could deal a conclusive blow to the regime. 'It is curious to see the crowds during the alarms: for many the fear is accompanied by the wish that the blow has been a big one, a wish they would never confess, but which is betrayed by their own behaviour. ${ }^{57}$

From the spring of I943, rumours spread by civilians were directly related to the desire for peace. In Bari, in May I943, a rumour circulated about an armistice between Germany and Russia. As a result, hundreds of women and children converged from every part of the city on the town hall square to demonstrate their joy. Similar events took place in Campania. ${ }^{58}$ Following the surrender in Africa in May 1943, even some Fascist leaders began to hope for the arrival of the Allies, in the belief that this would avoid a revolution in Italy which they increasingly feared. A few months earlier, the population in industrial areas had already begun to demonstrate signs of defeatism, as PNF informers confirmed in daily reports sent to Mussolini. In working-class districts particular attention was paid to Anglo-American leaflets reminding people of Italy's participation in the bombing of London in I94I. Although Italy's role had been inefficient and almost irrelevant, ${ }^{59}$ it had been emphasized in Fascist propaganda when Britain seemed near defeat, and now the British turned it against Mussolini. The claim of retaliation (which Churchill consistently supported from I94I) ${ }^{\mathbf{6 0}}$ was so pervasive in I943 that it was possible to hear Italians justifying enemy bombs on the grounds of the German and Italian raids on London. ${ }^{61}$ With the final surrender of the Axis in Africa on 13 May, there was a widespread sense that Allied bombing was both just and a means to end the war quickly:

Women return home from shopping exhausted, downhearted and often embittered after hours of queuing, cursing the war and those responsible for it, invoking the arrival of the

\footnotetext{
56 Legion of Carabinieri in Rome (area of Porta Appia) to Ministry of Interior, I4 May I943, ACS, MI, DGPS, IIGM, A5G, b. 62.

58 'Promemoria per il Duce', i7 May i943, ACS, MI, DGPS, IIGM, A5G, b. 6o.

59 Moreover, none of Italy's semi-obsolete aircraft ever made it as far as London. See the detailed listings of CAI's (Corpo Aereo Italiano) bombing and fighter patrol missions over Kent, Sussex, and Suffolk in Nino Arena, La regia aeronautica. 1939-1943, I (Rome, I98I), pp. 228-32.

60 Churchill to the House of Commons, 30 Sept. I94I: 'We have as much right to bomb Rome as the Italians had to bomb London last year, when they thought we were going to collapse' (TNA, Kew, AIR 20-2565).

61 Report by a PNF informer from Sesto San Giovanni (industrial periphery of Milan), 26 Jan. I943, ACS, MI, DGPS, Polizia politica, I927-45, b. 238, cited in Simona Colarizi, La seconda guerra mondiale e la Repubblica (Turin, I984), p. I8o.
} 
British and even bombing and death and with them liberation from so much discomfort and suffering. What happens in popular markets is indescribable. ${ }^{62}$

In Sicily, soldiers who had been overwhelmed by the quantity of modern armaments available to the Anglo-American armies in July I943 expressed admiration for the power of the invaders together with contempt for the Italian authorities who expected them to continue fighting the war despite such disparity of forces:

Strange, bizarre and fantastic stories have originated among the soldiers which reveal how much this war is alien and unreal for them and, as a war, almost incomprehensible. They explain to me that the twin-tailed aircrafts, the ones they are most scared of, are all piloted by women. I laugh, but they swear that it is true: among the remains of one of these planes they had even found the corpses of two beautiful blonde women, still miraculously intact but, God knows how, completely naked. And they are intensely fascinated by this idea of beautiful and ferocious women ... In all this there is the awareness of the crushing superiority of the enemy, but without anger; on the contrary with admiration and, in the enjoyment of telling me all these prodigies and wonders, they seem to forget about their fear. ${ }^{63}$

\section{I I}

The best-known legend - or perhaps psychotic suggestion - of Second World War Italy originated from those tensions and was the result of attempts (not always conscious) to cope with an ambiguous relationship in which the AngloAmericans made proclamations of friendship with the Italian people, while at the same time bombing cities, factories, ships, trains, and infrastructure where high numbers of civilians were inevitably present. The protagonist of the legend was a bizarre and cunning pilot (or, even, a sort of anthropomorphic plane), who acted in isolation. He was said to be constantly on the lookout for any small breach of the rules carried out by civilians; if he found any, he was said either to take photographs of the wrongdoer or even drop small bombs on them, all to remind them to look after their own safety and that of others. Many were convinced they had heard the buzz of this small aircraft's engine slowly circling their area. ${ }^{\mathbf{6 4}}$ According to some witnesses, the mysterious pilot even dropped leaflets warning of coming raids. ${ }^{65}$ A number of Italian websites, oral interviews, and war diaries now provide thousands of testimonies regarding the fear of this ghost-plane that

${ }^{62}$ Report by a PNF informer from Rome, 7June I943, ACS, MI, DGPS, Polizia politica, I927-45, b. 239, cited in Colarizi, La seconda guerra mondiale, p. I77.

${ }^{63}$ Giorgio Corona (army officer), 'Sicilia '43. Frammenti di taccuino', Nuovi argomenti, 5 (I957), pp. I4 $\mathrm{I}^{-}-2$.

64 Giovanni De Luna, 'La televisione e la "nazionalizzazione" della memoria', in Peppino Ortoleva and Chiara Ottaviano, eds., Guerra e mass media (Naples, I994), pp. 212-13; Cesare Bermani, Spegni la luce che passa Pippo (Rome, I996), pp. I6o-6.

${ }^{65}$ Cesare Bermani, 'L'immaginario collettivo di guerra: il mito di "Pippo",, in Paolo Ferrari, ed., L'aeronautica italiana (Milan, 2004), pp. 238, 25I. 
wormed its way into the life of the population. ${ }^{\mathbf{6 6}}$ Some sixty years on, people still recall that they had their sleep and nervous systems disturbed by the buzz of its engine. According to many, this mysterious plane simply observed from above that no one contravened the regulations regarding the blackout, alarms, and other oppressive rules imposed by the air defences. Although most witnesses claim that it was an Anglo-American aircraft, many cannot specify its nationality, or attribute to it an ambiguous one, such as an inoffensive Italian at the service of the enemy, or an Italian or German plane spying on them (thus blaming every negative phenomenon on the Axis).

When witnesses claim that the solitary plane dropped a small bomb, they add that it punished those who did not respect the rules. It is as if this invisible watchman personified the collective super-ego of a society that was subjected to the mechanisms of war but felt alienated from them. The imaginary plane/pilot was named Pippo, particularly in northern Italy but often also in the regions of central-southern Italy where American conquerors had arrived much earlier, and where it was also given other familiar or sarcastic nicknames such as Ciccio 'o ferroviere (Ciccio the railwayman) or l'Orfanello (the little orphan). In I944 at Montagnana near Padua a rumour spread that a ghost-plane was giving regular help to the partisans, 'every evening at I I the English plane named Pierino goes to supply the rebels' ${ }^{67}$

Some historians have explained this phenomenon of collective hallucination simply by the RAF tactic of nuisance raids (small but frequent bombardments designed to disturb) or through the use of reconnaissance planes looking for opportune targets on the peninsula, a tactic much intensified after the summer of I943, which was very dangerous for civilians but which was, however, rarely practised at night. Other scholars deny that the Anglo-Americans used the tactic of psychological warfare to maintain constant alarms every night over the whole Italian territory. ${ }^{68}$ In any case, these types of raids were not sufficient to explain the emergence of a nightmare of such characteristics and dimensions looming over the houses of the majority of Italians at the same time every night. It is too simple to identify Pippo with a number of RAF and USAAF planes like the twinengined Douglas A-2o Havoc, Bristol ${ }_{5} 56$ Beaufighter, De Havilland Mosquito, or the twin-boom plane Northrop P-6r Black Widow, or the single-engined North American P-5 I Mustang, as some scholars have done. ${ }^{\mathbf{6 9}}$

It is more appropriate to consider Pippo as the reaction of Italians, from north to south, to all those rules and fears that the bombing campaign generated in the collective unconscious. Moreover, the deficient Italian system for sighting raiding planes provoked regular and indiscriminate alarms every night, generating

${ }^{66}$ See also Alan R. Perry, 'Pippo: an Italian folklore mystery of World War II', Fournal of Folklore Research, 40 (2003), pp. II 5-48.

${ }^{67}$ Maria Carazzolo, Più forte della paura: diario di guerra e dopoguerra (1938-1947) (Sommacampagna, 2007), p. 204. See Bermani, 'L'immaginario collettivo di guerra', pp. 245, 250-I.

68 Alan R. Perry, "“Era il nostro terrore": Un'indagine sul mito di Pippo', Italia contemporanea, 225 (200I), pp. 599-600.

${ }^{69}$ Ibid., pp. 60o-I; Patricelli, L'Italia sotto le bombe, pp. 302-7. 
exhaustion and exasperation. This occurred during years in which the majority of the population was losing faith in Fascist totalitarianism and had the opportunity, for the first time, to read and listen to communications produced by the AngloSaxon world. The popular perception of this legendary threat should therefore be put into the context of a population that had become sceptical of the official information from military bulletins, the Italian radio, and the press, believing instead rumours from the streets - rumours which brought many bizarre and distorted stories which were often considered true by their disoriented listeners. ${ }^{\mathbf{7 0}}$ If Pippo represented to many a constant threat of ruin, to others it was a friendly counsellor, able to communicate with those on the ground and to warn of coming danger or even to bring good news. ${ }^{71}$ It is precisely this contradiction that brings us to conclude that these both friendly and frightening messages brought by the improbable pilot had much to do with the anomalous and intense relationship that emerged, particularly from I943, between the formation of a free Italian public opinion and the propaganda dropped by the enemy from the sky.

The Fascist reaction to these legends and to enemy propaganda showed to what extent the regime was losing control of the media and of the population. Since the Ethiopian war, the regime had implemented methods to get the population used to the idea of living with war. In particular, an office of propaganda and instruction had been created, the UNPA (National Union of Anti-Aircraft Protection) based in Milan which focused on instructing civilians on ways to resist air raids. However, the Fascist response to Allied propaganda was basic and unsophisticated, concentrating on appeals not to surrender or fraternize with the enemy. In the spring of 1943 , one leaflet - remembered by a man from Palermo who was going to be made the vice-secretary of the Fascist party - read, sarcastically: 'Italians! Do read the enemy's leaflets: they incite you to cowardice. The enemy bombs aim at killing you. The leaflets at dishonouring you. The bombs want your physical death, the leaflets your civil death. ${ }^{72}$ But on the ground, even the Sicilian Fascist authorities wondered why the Italian air force was using its few remaining planes to drop such crude propaganda, whose effects could only be self-defeating. ${ }^{73}$

70 'It is an endless stream of rumours, news, information, to the point that sometimes you cannot stand it any more', wrote a student from Padua in her diary on 20 Aug. I944 (Carazzolo, Più forte della paura, p. 20I). See Marc Bloch, Réfléxions d'un historien sur les fausses nouvelles de guerre (192I), in Bloch, Mélanges historiques (Paris, I963), II; Marie Bonaparte, Mythes de guerre (Paris, I950); Paul Fussel, Wartime: understanding and behavior in the Second World War (Oxford, I989); Pietro Cavallo, Italiani in Guerra: sentimenti e immagini dal 1940 al 1945 (Bologna, 1997).

71 In one version from a Venetian witness, 'the famous plane Pippo' was shot down towards the end of I943, but the parachute which saved the life of the pilot, taken in an adventurous manner from the Germans, continued to have beneficial effects, allowing the manufacture of silk shirts for an entire family of extremely poor boatsmen (interview by Giorgio Crovato to Luciano D'Este, i6 July 2003).

72 Text of leaflet in Alfredo Cucco, Non volevamo perdere (Bologna, I950), p. 26.

${ }^{73}$ Gaetano Zingali, L'invasione della Sicilia (I943) (Catania, I962), p. I03. See Vittorio Zincone, 'Note e discussioni: stampa e propaganda in tempo di guerra', Critica fascista, Io (I943), pp. 526-33. 
Having failed to counteract enemy propaganda, in the spring of I943 the Fascists invented, as a kind of antidote, news that aimed at creating fear of what the enemy might drop. They spread the rumour that the Anglo-Americans dropped explosives in the shape of toys, dolls, butterflies, pencils, pens, or cigarette holders, or poisoned sweets, in order to deceive and kill gullible Italians, in particular children, who were curious and naive (as all Italians were supposed to be at this point).

The newspapers unleashed this news after the bombing of the small Tuscan city of Grosseto on 26 April i943. A massive and continuous week-long radio and press campaign described in detail, with illustrations, these insidious traps. ${ }^{74}$ The campaign was extended to popular illustrated magazines, which outspokenly accused the 'gangsters of the air' in large drawings which showed pilots leaving for Italy and stopping to buy toys in the shops of sadistic arms dealers. ${ }^{\mathbf{7 5}}$ The British worried about the spreading of this news in the Italian press: 'clearly the pen story must be an invention' ran a telegram from the Air Ministry to the Mediterranean Air Command; however, 'unfortunately such tales are still believed'. They requested an inquiry to ensure that explosive fountain pens were not actually bomb detonators, and argued that Radio London must explain that the story had been invented. ${ }^{76}$ Some Fascist leaders took the regime's propaganda so seriously that they protested to the International Red Cross and to Vatican prelates. The latter fell victim to the same belief and persuaded the Vatican, which was normally very prudent, to make a formal protest to the British and the American ambassadors. The loss of face suffered by the Vatican as a result provoked a growing sense of irritation on the part of the Vatican's representatives towards the Fascist authorities. ${ }^{77}$

The creation of alarm about objects that enemy aircraft might drop from the sky was designed to shield the population from Allied propaganda. After only a few days, however, this campaign had devastating effects by generating uncertainties among children and families. Panic spread across Italy, and in the process the propaganda that had sought to strengthen the home front was undermined. On 20 May i943, the marquess Iris Origo described in her diary the reactions of the Roman population:

The papers continue to publish accounts of objects containing explosives which are supposed to have been dropped by Allied planes with the object of mutilating women and children: fountain-pens, pencils, watches, lipsticks, and even dolls and cough-drops! and they publish photographs of children wounded by picking up these objects. Some are supposed to have fallen at Civitavecchia and Ostia, but I have never met anyone who has

74 'Le matite e le stilografiche esplosive', L'Avvenire d'Italia, 7 May I943; 'Il barbaro nemico', La Domenica del Corriere, I6 May I943.

${ }^{75}$ Il Travaso delle idee, in particular the issue of $\mathrm{I} 6$ May I943, but see also the following issues.

${ }^{76}$ Secret telegram from Air Ministry to headquarters of Mediterranean Air Command, 3 May I943, TNA, Kew, AIR 20-5304.

77 Giuseppe Bottai, Diario, 1935-I944, entry of I June I943 (Milan, 200I), p. 380; Alberto Pirelli, Taccuini, 1922/1943 (Bologna, 1984), p. 434. 
actually seen or touched one. Every child in Rome has been solemnly warned never, never to pick up anything in the street or it will go off with a bang ... 'It's the Germans who have dropped them', is a frequent comment. ${ }^{78}$

Between I8 May and 2 June I943 Ministry of Popular Culture directives to the press sought to limit the psychological reaction, repeatedly asking the newspapers to end their interest in child-killing objects. The 'news', which quickly became the topic of the day, had revealed itself to be counter-productive. ${ }^{79}$ Moreover, many began to believe that it was the Fascists, or the Germans, who had spread the objects with the purpose of blaming the enemy. On 3i July I943, only a few days after Mussolini had been overthrown, one of the most sensational rumours circulating in Rome was that the Duce had personally distributed these lethal objects delivered from Germany; it was the long-awaited final proof of the dictatorship's criminal malice and falsehood. One of the many secret informers to the Fascist police reported:

A cry of horror expresses the general outrage at the discovery by the firemen in Mussolini's apartment in Palazzo Venezia and in the headquarters of the now defunct Fascist Party of cases full of explosive fountain-pens made in Germany. People say: here we are, these are the infamous methods used by the tyrant to ignite hatred for Britain: it was him, not the enemy, who mutilated the flesh of our children in the name of his vile ambition. ${ }^{80}$

But this was not the end of the story. The following winter, the Germans, having occupied central-northern Italy and wanting to terrify Italians, put up posters carrying alarmist news - amplified by the newspapers of the new Fascist Republican regime - which re-awakened the nightmare. Now, children began to be alarmed by the imaginary threat of the 'butterfly-bombs'. ${ }^{81}$ Once again, however, people attributed their diffusion not only to the Anglo-Americans but to any of the belligerents. ${ }^{82}$

\section{V}

Some of the regime's intellectuals were shocked by the willingness with which their compatriots believed enemy propaganda, and attributed this to the congenital weakness of the Italian character. ${ }^{83}$ The reaction of the Italian population to air raids and to psychological warfare was always carefully observed, evaluated, and discussed in international political circles - by the British and Americans,

78 Iris Origo, War in Val d'Orcia: an Italian war diary, I943-I944 (London, 2005; ist edn I947), p. 47. The author, born to an American mother and British father, was married to a Tuscan aristocrat.

79 Fausto Coen, Tre anni di bugie (Milan, I978), pp. I52-3.

80 Anonymous report from Rome, 3I July i943, ACS, MI, DGPS, Polizia politica, Materia, b. 239.

81 See Bermani, Spegni la luce che passa Pippo, pp. 159-6o; Carazzolo, Più forte della paura, p. 237.

82 During the war, the Germans did drop cluster anti-personnel bombs, which in England were called 'butterfly bombs', and exploded once they were picked up. However, they were not disguised as toys or created with the intent of killing children. Propaganda to demonize the enemy and popular imagery developed the stereotype of a criminal project to capture children's attention and to slaughter them. ${ }^{83}$ Salvatore Satta, De profundis (Milan, I980; ist edn I948), pp. 64-8o. 
by Italian and German observers and by the neutral but not disinterested Vatican diplomats. ${ }^{84}$ The former foreign minister, ambassador to London and eventually minister of justice Dino Grandi observed at different phases - throughout the first eight months of I943 - the Anglo-American attempt to provoke, through bombs and propaganda, what he defined as a 'popular revolution' against the national institutions in Italy. ${ }^{85}$ Although the use of leaflets was common practice in the propaganda efforts of all states engaged in the war, the reaction to both leaflets and bombs seemed to provoke popular protest and collapse of morale in Italy especially. This was the case even when, in I942, the amount of bombs dropped was relatively low, if compared to those dropped in $1943^{-5} .^{86}$

Particularly from the end of 1942 civilians began to feel unconnected to the dictatorship and, after a first round of factory strikes in March and April I943, to hope for a military coup supported by the king. The ambiguous perception of the enemy began to extend especially to the German ally which was regarded with growing hostility, not only because of the increasing presence of German troops on Italian soil but also for the reasons suggested by Anglo-American propaganda, which had by then broken the Fascist monopoly of information. The difficulty in adapting coherently to the demands of the various belligerents generated feelings of guilt that were difficult to acknowledge at a conscious level. What was evident was that civilians began to detach themselves from the Fascist war and to become attracted to Anglo-American arguments about the need to get rid of the alliance with Germany.

The outcome of the war and its interpretation as a conflict between fascism and democracy has fixed in popular memory the idea that the Allies 'had to' use bombing - and Anglo-American propaganda succeeded in persuading Italians that there was a link between bombs, democracy, and liberation. One woman's war-time diary, published in Rome in I945, illustrates how this idea had been successfully constructed even before the war was over: 'An enemy that had to hurt us deeply and to whom, however, we cannot bear resentment. On our poor defenceless body he had to strike the cancer that was devouring us, cutting the flesh just like the surgeon with the scalpel. ${ }^{87}$ However, the experience of being bombed did not bring straightforward answers. Civilians' feelings were often divided, even when they had become detached from Fascism. In her war-time diary from Rome during the summer of i943, the writer Jolanda di Benigno noted:

And the bombing! We would have said that the 'allies' were like Hitler ... Everyday we switched the radio on with shaking hand and the eye fixed on the terrible questions: which of our dear, illustrious, courageous cities has been violated last night? How many more

84 Silveri and Carli, Bombardare Roma.

85 Dino Grandi, 25 luglio 1943 (Bologna, 2003; ist edn I983), pp. 3I4-20.

86 See Arthur Harris, Despatch on war operations: 23rd February 1942 to 8th May 1945 (London, 1995).

87 Anna Garofalo, In guerra si muore (Rome, I945), p. 8. 
dead? ... And the bombs ... the 4,ooo pound-bombs, death that comes from where we look when we pray to God. ${ }^{88}$

Among witnesses interviewed on the bombing of Treviso and Milan it is possible to find a similar uncertain attitude - resentment of the bombers is never expressed, although it is occasionally implicit in the narrative. ${ }^{89}$ For those who had a family member in the army, for the men who left home as soldiers believing in the Fascist war, things were especially complicated, as it was more difficult to hope that the war would be lost. Grazia Pagliaro, a young woman in Palermo during the war, explained in her diary that when the Anglo-Americans arrived, they claimed to be the enemies of Fascism, not of the Italians, 'but this does not change the fact that what is happening is terribly humiliating and makes the memory and the pain of the disasters even more alive'. ${ }^{\mathbf{9}}$ Despite the fact that Allied correspondence and reports have confirmed that the majority of the population welcomed them as liberators, ${ }^{91}$ the feelings of civilians were still often confused. The arrival of the Allies was generally awaited and hoped for because it meant the end of the war, or so it was believed. On the contrary, from August I943 the raids increased in number and intensity. The two moments of palingenesis, 25 July and 8 September, did not produce the expected miracle because the war and the bombing continued.

The relationship with the bombers was complicated also because cities became symbolic and emotional spaces which had to be defended by their inhabitants when their 'soul' was wounded: for many civilians, an outrage to their home town was an outrage to the motherland. Grazia Alfieri Tarentino, a young woman in Milan from I94I, for example, expressed a painful resentment of the enemy when she saw La Scala theatre on fire: it was 'all that had remained of the heart of the city'. In October I944, when a bomb killed 200 school children in the working-class Gorla district of Milan, she witnessed the tragedy of the death of innocent children. The whole city was in mourning on the day of the funerals, the women in black beside the small white graves:

On the church square, among the silent crowd, someone dared to say: "these are the Anglo-Americans, assassins of children'. Propaganda insinuated itself alongside the sincere pain; on the walls posters appeared with images of death to remind those who persisted in refusing to believe it, that the so-called 'liberators' were the enemies ... Ideas were confused. ${ }^{92}$

${ }^{88}$ Jolanda Di Benigno, Occasioni mancate: Roma in un diario segreto, 1943-1944 (Rome, I945), p. 95.

89 Achille Rastelli, Bombe sulla città: gli attacchi aerei alleati: le vittime civili a Milano (Milan, 200o); Luisa Tosi, ed., Testimoni loro malgrado: memorie del bombardamento del 7 aprile 1944 (Treviso, 2006).

90 Grazia Pagliaro, Giomi di guerra in Sicilia: diario per la nonna, 9 maggio-8 agosto 1943 (Palermo, I993), pp. 26, 53 .

91 Nicola Gallerano, 'L'arrivo degli alleati', in Mario Isnenghi, ed., I luoghi della memoria: strutture ed eventi dell'Italia unita (Rome and Bari, 997), p. 459.

92 Grazia Alfieri Tarentino, La festa di Muncalè: storia minore della gente di Milano che qualcuno vorrebbe mettere nella zona grigia senza averne conosciuta la vera natura (Genoa, 2005), pp. II7, I76. 
Among the confusion and suffering of events like Gorla, Fascist propaganda did not, however, obtain the results it hoped for; at this final stage of the war in particular, it had no arguments left apart from emphasizing the criminality of the enemy.

\section{$\mathrm{V}$}

The Allies analysed and discussed the consequences of bombing on Italians' behaviour and morale throughout the war. Particularly from late autumn I942, after six night attacks on Genoa, seven on Turin and one daytime attack on Milan, Bomber Command realized that against Italy's weak defences, and with the excellent visibility that was usual given the Italian climate, it was easier to attack Italy than Germany. Moreover, even though the attacks were still lighter than those directed against Germany at that time, 'the effect on Italian morale was enormous and out of all proportion'. ${ }^{93}$ On 2 December I942, Mussolini went on Italian radio and declared that it was necessary to organize a nightly evacuation of all civilians in the industrial cities of northern Italy. ${ }^{94}$ This increased panic and lowered morale, as Italians realized that evacuation represented the only anti-aircraft 'solution'. Indeed, Air Marshal Harris was surprised that 300,000 people, half the population of Turin, abandoned the city en masse, and that panic had probably been even greater after the daylight attack on Milan 'by less than one hundred Lancasters' ${ }^{\mathbf{9 5}}$ The Allies could take advantage of Italian unpreparedness for war, presenting themselves in the propaganda as liberators and blaming Mussolini as the principal responsible for the war. Italians' reactions to bombing and propaganda included forms of non-compliance with the militarization of society; the tendency to blame disaster on the Axis rather than on the enemy; and the spread of rumours that challenged the regime's propaganda, and of legends which revealed feelings of admiration for the enemy's strength. However, collective pain and mourning after devastating raids which killed high numbers of civilians occasionally helped Fascist propaganda. After the October I944 bombing of Milan, for example, feelings appeared to be confused when Fascist posters defined the Allies as assassins of children. On I6 December of that year (at the time of the German counter-attack in the Ardennes), Mussolini gave a public speech in Milan in which he defined Italy as an 'immense battlefield covered in ruins'. Responsible for this crime were both the Allies and the traitors who had followed Badoglio. ${ }^{96}$ Although this speech received a favourable response from

93 Arthur Harris, Bomber offensive (London, I99o; ist edn 1947), p. I40.

94 Benito Mussolini, Opera Omnia, Xxxi: Dal discorso al direttorio nazionale del P.N.F. del 3 gennaio I942 alla liberazione di Mussolini: 4 gennaio 1942-I2 settembre 1943 (Florence, I960), pp. II8-33.

95 Harris, Bomber offensive, p. I4I.

96 Benito Mussolini, Opera omnia, xxxII: Dalla liberazione di Mussolini all'epilogo: la Repubblica sociale italiana: I3 settembre 1943-28 aprile 1945 (Florence, I960), pp. I26-39. 
the audience, by the end of 1944 the majority of Italians was waiting for the Allies as the only hope that the war would end, and Fascist propaganda successes were short-lived. As the article has explained, Allied propagandaby-bombing was effective in disorientating Italians' sense of patriotism from the early stages of the campaign. 